International Research Journal of Management, IT \& Social Sciences
Available online at https://sloap.org/journals/index.php/irjmis/
Vol. 6 No. 4, July 2019, pages: 86 96
ISSN: 2395-7492
https://doi.org/10.21744/irjmis.v6n4.661

\title{
Debt Covenant Slack, Earnings Management, and Value Relevance of Accounting Information
}

Ni Putu Sintya Purnama Dewi
Dewa Gede Wirama $^{\text {b }}$

\section{Article history:}

Received: 27 March 2019

Accepted: 31 May 2019

Published: 28 June 2019

\section{Keywords:}

covenant;

debt;

earnings management;

slack;

value relevance;

\begin{abstract}
This study aims to examine the effect of debt covenant slack on the value relevance of accounting information, and whether earnings management works as an intervening variable. A total of 40 non-financial companies listed in Indonesia Stock Exchange from 2013 to 2017 were selected as sample. Three hypotheses were tested using partial least square and analyzed via path analysis. This study found that debt covenant slack positively affects the value relevance of accounting information. Possibly, the tendency of small debt covenant slacks in the firms causing the information of firms' performance to be less relevant for the investor because they believe that the firms will prioritize the debt payments rather than dividends. Furthermore, empirical evidence from this study indicates that debt covenant slack affects investors' decision in using firms' performance information. However, no statistically significant effect was found neither on the relationship between debt covenant slack and earnings management nor on the relationship between earnings management and the value relevance of accounting information. Hence, earnings management is not an intervening variable in the effect of debt covenant slack on the value relevance of accounting information.
\end{abstract}

2395-7492@ Copyright 2019. The Author. This is an open-access article under the CC BY-SA license (https://creativecommons.org/licenses/by-sa/4.0/) All rights reserved.

Author correspondence:

Ni Putu Sintya Purnama Dewi,

Faculty of Economics and Business, Udayana University, Denpasar, Indonesia

Email address: rasumaputri80@gmail.com

\section{Introduction}

The effect of the company proximity to the breach of debt covenant on earnings management is explained by the debt covenant hypothesis in Positive Accounting Theory proposed by Watts \& Zimmerman (1978). The theory predicts that when a company is close to its debt covenant violation, the manager tends to increase profits by shifting the earnings of the next period to the current period.

\footnotetext{
${ }^{\text {a }}$ Faculty of Economics and Business, Udayana University, Denpasar, Indonesia ${ }^{\mathrm{b}}$ Faculty of Economics and Business, Udayana University, Denpasar, Indonesia
} 
In explaining and predicting earnings management actions, managers are assumed to be rational and try to maximize their utility. On the other hand, in the company, there is also a separation of ownership and management functions that give rise to information asymmetry, where managers have more information about the company than shareholders (Jensen \& Meckling, 1976). The implication is that managers will choose accounting policies that are more profitable for them. Thus, when a firm is close to the debt covenant violation, the manager will try to make the firm's earnings higher than the actual earnings by moving the earnings from the future period into the current period (Watts \& Zimmerman, 1978).

The debt covenant hypothesis in positive accounting theory has been confirmed by some empirical evidence obtained from Sweeney (1994); Herawati \& Baridwan (2007); and Dyreng et al., (2011). All of these studies found that managers manage earnings upward when the company violates its debt covenant to avoid the cost of technical default (Sweeney, 1994).

The pattern of earnings management carried out by managers when the firm is close to the breach of the debt covenant is not limited to the activity of income increasing only. Empirical studies from DeAngelo et al., (1994) and Jha (2013); present findings that management opportunistically manages earnings downward when the company violates its debt covenant. Managers prefer to decrease earnings to show that the company is in its financial difficulties so the creditors might set less restrictive debt covenants during the renegotiations that follow defaults (DeAngelo et al., 1994).

Several previous studies such as those conducted by Duke \& Hunt (1990) and Press \& Weintrop (1990), use the firms' debt to equity (DER) ratio to reflect the firms' closeness to its debt covenant violation. The results of these studies indicate that the actual DER is a valid proxy to measure the closeness of a company to its debt covenant violation. However, Leftwich (1983), and Kim et al., (2010), claim that the actual DER is not a direct proxy that can show how close the firms to their debt covenant violation. Moreover, the use of a single DER actual as a proxy might cause problems of interpretation (Leftwich, 1983). Thus, empirical studies of Dichev \& Skinner (2002); Kim et al., (2010); and Demerjian \& Owens (2014), anticipate this problem by using a proxy in the form of "slack", whose calculation includes a threshold (maximum or minimum ratio) required in the firms' debt agreements with creditors.

Debt covenant slack is the difference between the threshold value required in the debt covenant with the actual value obtained by the company (Dichev \& Skinner, 2002; Demerjian \& Owens, 2014). The smaller the value of the debt covenant slack, the closer the company to the breach of its debt covenant. From the debt covenant hypothesis perspectives, it means that companies that tend to do earnings management are those whose value of the debt covenant slack tends to be small (Demerjian \& Owens, 2014; Kusuma \& Yasa, 2019; Dewi et al., 2018). This has been confirmed by empirical findings from Kim et al., (2010) and Franz et al., (2014), who found that the debt covenant slack negatively affects the earnings management.

On the other hand, the existence of opportunistic earnings management in the company potentially reduces the value relevance of accounting information (Whelan \& McNamara, 2004). The value relevance of information presented in financial statements is influenced by the investors' perceptions of the reliability of the information presented. Investors are assumed to be rational and sophisticated so that they can detect earnings management. The existence of opportunistic earnings management causes the reliability of the information being questioned by investors. This is because earnings management causes the information presented by the company in their financial statements are no longer reflect the actual performance of the company (not faithfully representative) so that the information will not be trusted by investors. Investors might not use such information on their decision making so that the investors' response on that information will not be reflected in the firms' stock price (Chandrapala, 2013; (Mandala \& Astika, 2019; Sukardi, 2019). Research conducted by Habib (2004); Rahman (2009); Shan (2014); and Mostafa (2017), confirmed the evidence obtained by Whelan \& McNamara (2004). All of these studies found that earnings management has a negative effect on the value relevance of accounting information.

This study attempts to examine the effect of debt covenant slack on the value relevance of accounting information by using earnings management as an intervening variable. A total of 40 companies listed on the Indonesia Stock Exchange (IDX) during the period 2013 to 2017 were selected through purposive sampling. The adjusted $\mathrm{R}^{2}$ from the regression of earnings per share and book value per share on share price is used as the value relevance proxy. Earnings management is proxied by the average value of absolute discretionary accruals over the observation period. Debt covenant slack is proxied by the average value of DER slack from 2013 to 2017.

Dewi, N. P. S. P., \& Wirama, D. G. (2019). Debt covenant slack, earnings management, and value relevance of accounting information. International Research Journal of Management, IT and Social Sciences, 6(4), 86-96. https://doi.org/10.21744/irjmis.v6n4.661 
Literature Review and Hypotheses Development

\section{Value Relevance}

Historically, the notion about the value relevance of accounting information emerged from the initial event study conducted by Ball \& Brown (1968), which found that the firms' earnings have information content and related to the firms' stock price. However, further empirical evidence presented by Lev (1989), indicates that the firms' earnings information can only explain $2-5 \%$ variability of company's stock returns, thereby raising the question about how relevant the earnings information for the investor.

Information is said to be value-relevant if it has an association with equity market value (Barth et al., 2001). Typically, the value relevance of accounting information is measured as the adjusted $\mathrm{R}^{2}$ of regression with earning per share and book value per share as the independent variables and the stock price as the dependent variable. The statistical relation between earnings and book value with the stock price reflects the relevance of accounting information and also the consequences of investors' action (Lev \& Zarowin, 1999). The relatively small value of adjusted $\mathrm{R}^{2}$ means that the information is less relevant for the investor, vice versa.

\section{Earnings Management}

Earnings management occurs when managers use their judgments to take actions that can mislead shareholders about company performance (Healy \& Wahlen, 1999). Generally accepted accounting principle gives the manager some flexibility to choose an accounting method to be used in their firms. Managers are assumed to be able to make judgments about the most suitable accounting method for the firms. However, managers' judgments are often influenced by certain motivations so that the flexibility is used by managers to act opportunistically by choosing the accounting methods that are actually not appropriate to be applied in the firms (Pae, 1999).

One of the motivations that are said to encourage managers to do earnings management is a violation of firms' debt covenant restrictions. Debt Covenant Hypothesis on the Positive Accounting Theory states that ceteris paribus, the closer the firms to the violation of their debt covenant, the more likely the manager manage the firms' earnings (Watts \& Zimmerman, 1978). Some empirical studies found that the manager manages earnings upward to relax the tight slack so they can avoid technical default (Sweeney, 1994; Herawati \& Baridwan, 2007; Dyreng et al., 2011). Other empirical evidence found that manager manages earnings downward so that the company appears to be unhealthy, in order to get a waiver or less restrictive covenant in their renegotiation with creditors (DeAngelo, 1994; Jha, 2013).

Debt Covenant Slack

Generally, the firm's funding comes from two main sources, i.e. debt from the lenders and equity from the shareholders (Frantz, 1997). When the firm borrows from its creditor, their debt agreement usually contains some constraint to be fulfilled by the firms, such as the maximum or minimum of certain financial ratio (Janes, 2003). The violation of the debt covenant might lead the firms into a technical default which results in some high default cost as the consequences. These costs can consist of the increased collateralization, restriction on further borrowing, and increased interest rates (Sweeney, 1994).

The firms' closeness to its debt covenant violation can be measured by the debt covenant slack. Debt covenant slack is the difference between the threshold (maximum or minimum) of the firms' financial ratio and the actual ratio obtained by the firms (Demerjian \& Owens, 2014). The lower (tighter) the slack, the closer the firm to its debt covenant violation. For the covenant with a maximum threshold, the null and negative value indicates that the firm has violated the covenant.

\section{Hypotheses Development}

\section{The effect of debt covenant slack on earnings management}

Debt covenant hypothesis stated that the closer a firm to its debt covenant violation, the more likely the firms' manager is to select income increasing accounting procedures (Watts \& Zimmerman, 1987). Managers try to relax the tightness of accounting-based restrictions on the debt agreement, so they can avoid technical default (Sweeney, 1994). Moreover, DeAngelo et al., (1994) and Lee (2000), found that when the firms are close to their covenant violation, managers are likely to manage the earnings downward to show the firms' unhealthy financial condition. One explanation for this condition is the managers are trying to increase the firms' bargaining power, so the firms could 
get waiver from the creditors during renegotiations. Prior empirical evidences from Kim et al., (2010), Jha (2013), and Franz et al., (2014), are also found that the debt covenant slack has a negative effect on earnings management.

Based on the description, this study considers that the smaller (tighter) the debt covenant slack, the more likely the firms' managers manage their earnings opportunistically. Thus, the first hypothesis in this study is stated as follows.

H1: Debt covenant slack has a negative effect on earnings management.

\section{The effect of earnings management on the value relevance of accounting information}

This study assumed that investors are rational and sophisticated so they can detect opportunistic earnings management. The existence of earnings management in firms decreases the reliability of the information so it became no longer trusted by the investor. An investor might decide not to use such information in making decisions. Thus, the information which is contained manipulation becomes less relevant, thereby reducing the explanatory power of such information in explaining the stock price (Whelan \& McNamara, 2004).

Empirical studies conducted by Habib (2004); Rahman (2009); Shan (2014); and Mostafa (2017), confirm the evidence presented in Whelan \& McNamara (2004), by providing empirical evidence that earnings management has a negative effect on the value relevance of earnings and book value. Based on the description, this research, therefore, predicts that the more likely the firms' manager manage their earnings opportunistically, the less the value of adjusted $\mathrm{R}^{2}$ obtained from the regression of earnings and book value on the firms' share price. Thus, the second hypothesis in this study is stated as follows.

H2: Earnings management has a negative effect on the value relevance of accounting information.

\section{The effect of debt covenant slack on the value relevance of accounting information}

Empirical evidence about the effect of debt covenant slack on the value relevance of accounting information has not found yet, but another similar study found that the earnings response coefficient (ERC) of firms having lower DER tend to be smaller than ERC of firms having higher DER (Dhaliwal et al., 1990; Moradi et al., 2010). One explanation is that on the firms which tend to lever by higher debt than equity, the information about the firms' earnings will be more valuable for a creditor because the investor believes that the firms will prioritize their debt payments rather than a dividend. Thus, the investor did not use firms' performance information (earnings and book value) as the basis of their decision making, thereby making such information to be less relevant and reduce the explanatory power of that information.

Based on the explanation, this study predicts that the smaller (tighter) the debt covenant slack, the value relevance of accounting information i.e. earnings and book value also tends to be small. The small (tight) value of the debt covenant slack shows that the firms' actual DER tends to be high and close to the maximum DER limit or even has exceeded the maximum DER required in the debt covenant. In accordance with the empirical evidence presented by Dhaliwal et al., (1990) and Moradi et al., (2010), this condition causes the firms' performance information to be less relevant for investors because they perceive that the earnings gained by the firms will be used first to pay the debt. Thus, the value relevance of firms' performance information will tend to be small. The third hypothesis in this study is presented as follows.

H3: Debt covenant slack has a positive effect on the value relevance of accounting information.

\section{Materials and Methods}

\section{Research Design, Sample, and Data Collection}

This study is associative causality research which aims to obtain empirical evidence related to the effect of debt covenant slack on the value relevance of accounting information through earnings management as an intervening variable. This research was conducted on the Indonesia Stock Exchange (IDX). The observation period in this study was from 2013 to 2017. The population in this study includes all nonfinancial firms listed on the IDX from 2013 to 2017. A total of 40 samples were collected through purposive sampling with several criteria as follows.

a) The company belongs to non-financial sector firms listed in IDX over the period 2013 to 2017. Firms belong to the financial industry are excluded in this study due to the specific financial characteristics of financial firms that are different from firms in another industry (Widowati et al., 2013).

Dewi, N. P. S. P., \& Wirama, D. G. (2019). Debt covenant slack, earnings management, and value relevance of accounting information. International Research Journal of Management, IT and Social Sciences, 6(4), 86-96. 
b) The company discloses its debt agreement in the notes of financial statements, which contains the maximum debt to equity ratio (DER) during 2013 to 2017.

c) The company publishes its quarterly and annual financial reports for twenty two quarters starting from the third quarter of 2013 until the fourth quarter of 2017.

d) The financial statements contain the data needed in this study which includes the value of liabilities, equity, earnings, operating cash flows, total assets, revenue, account receivables, book value, and also the value of gross property, plant, and equipment (PPE).

All the financial data were collected through documents gained from the official website www.idx.co.id and the share price data were gained from www.finance.yahoo.co.id. Three hypotheses in this study were tested using PLS (Partial Least Square) and analyzed via path analysis.

\section{Variables and measures}

1. Value relevance of accounting information

This study use the adjusted $\mathrm{R}^{2}$ value from the regression of earnings per share and book value per share on share price as a proxy for accounting information's' value relevance. To avoid bias, the regression model is deflated by the lagged price (Brown et al., 1999) as used by the prior research by Widyatama \& Wirama (2018), as follows.

$$
\frac{P_{i, t}}{P_{i, t-1}}=\alpha_{0}+\alpha_{1} \frac{E P S_{i, t}}{P_{i, t-1}}+\alpha_{2} \frac{B V P S_{i, t}}{P_{i, t-1}}+\varepsilon_{i, t}
$$

Where

$\mathrm{P}_{\mathrm{i}, \mathrm{t}} \quad$ : Adjusted close price share firm from the publication date for quarter $\mathrm{t}$

$\mathrm{P}_{\mathrm{i}, \mathrm{t}-1} \quad$ : Adjusted close price share firm $\mathrm{i}$ on the publication date for quarter $\mathrm{t}-1$

BVPS $_{\text {it }} \quad$ : Book values per share firm $i$ at the end of quarter $t$

EPS $_{\text {it }} \quad$ : Earnings per share firm $\mathrm{i}$ in quarter $\mathrm{t}$

$\varepsilon_{\text {it }} \quad:$ Error term

\section{Debt Covenant Slack}

Debt covenant slack in this study is measured by the average value of DER slack over the period 2013 to 2017. Based on Demerjian and Owens (2014), DER slack is measured as follows.

$$
\text { DERslack }_{\text {it }}=\text { DERmaximum }_{\text {it }}-\text { DERactual }_{\text {it }}
$$

Where

DERslack $_{\text {it }}$ DERmaximum DERactual
: Debt to equity ratio slack of firm $\mathrm{i}$ in quarter $\mathrm{t}$

: Maximum debt to equity ratio required in the debt covenant of firm $\mathrm{i}$ in quarter $\mathrm{t}$ : Total debt divided by total equity of firm $i$ in quarter $t$

\section{Earnings management}

This study uses the average value of the absolute discretionary accruals over the period 2013 to 2017 as a proxy of earnings management. The absolute value were used to avoid bias in the interpretation which is tend to interpret negative discretionary accrual as lower earnings management than the positive ones. To estimate discretionary accruals, this study use the version of Modified Jones Model presented by Dechow et al., (1995), which is described as follows.

$\mathrm{TA}_{\mathrm{it}}=$ Earnings $_{\mathrm{it}}-\mathrm{CFO}_{\mathrm{it}}$

$\mathrm{TA}_{\mathrm{it}} / \mathrm{A}_{\mathrm{it}-1}=\alpha_{1}\left(1 / \mathrm{A}_{\mathrm{it}-1}\right)+\alpha_{2}\left(\Delta \mathrm{REV}_{\mathrm{it}} / \mathrm{A}_{\mathrm{it}-1}\right)+\alpha_{3}\left(\mathrm{PPE}_{\mathrm{it}} / \mathrm{A}_{\mathrm{it}-1}\right)+\varepsilon_{\mathrm{it}}$

$\mathrm{NDA}_{\mathrm{it}}=\alpha_{1}\left(1 / \mathrm{A}_{\mathrm{it}-1}\right)+\alpha_{2}\left(\Delta \mathrm{REV}_{\mathrm{it}} / \mathrm{A}_{\mathrm{it}-1}-\Delta \mathrm{REC}_{\mathrm{it}} / \mathrm{A}_{\mathrm{it}-1}\right)+\alpha_{3}\left(\mathrm{PPE}_{\mathrm{it}} / \mathrm{A}_{\mathrm{it}-1}\right)$

$\mathrm{DA}_{\mathrm{it}}=\left(\mathrm{TA}_{\mathrm{it}} / \mathrm{A}_{\mathrm{it}-1}\right)-\mathrm{NDA}_{\mathrm{it}}$

Where

$\mathrm{TA}_{\text {it }} \quad$ : total accruals firm $\mathrm{i}$ in quarter $\mathrm{t}$

Earnings $_{i t} \quad$ : net earnings firm $\mathrm{i}$ in quarter $\mathrm{t}$

$\mathrm{CFO}_{\text {it }} \quad:$ cash flows from operating activities firm $\mathrm{i}$ in quarter $\mathrm{t}$

$\mathrm{A}_{\text {it-1 }} \quad$ : total assets firm $\mathrm{i}$ at $\mathrm{t}-1$ 
$\triangle \mathrm{REVit} \quad:$ revenues firm $\mathrm{i}$ in quarter $\mathrm{t}$ less revenues firm $\mathrm{i}$ in quarter $\mathrm{t}-1$

$\triangle \mathrm{REC}_{\mathrm{it}} \quad:$ net receivables firm $\mathrm{i}$ in quarter $\mathrm{t}$ less net receivables in quarter $\mathrm{t}-1$

PPEit $\quad$ : gross property, plant, and equipment firm $\mathrm{i}$ in quarter $\mathrm{t}$

$\mathrm{NDA}_{\mathrm{it}} \quad$ : non discretionary accruals firm $\mathrm{i}$ in quarter $\mathrm{t}$

$\alpha \quad:$ firm spesific parameter

$\varepsilon_{\text {it }} \quad$ : eror term

\section{Data Analysis Technique}

Data were analyzed through path analysis using Partial Least Square. On the hypothesis testing, this study uses one tailed testing because all the hypotheses in this study use sign (positive/ negative). To determine whether the variables relation are significant or not, we compared the $\mathrm{p}$-value with the significant level $(0,05)$. The relation are considered to be significant if the p-value is smaller than 0,05 . On the contrary, the relation is considered to be not significant if the $\mathrm{p}$-value is greater than 0,05 .

\section{Results and Discussions}

\section{Descriptive Statistics of Variables}

There are three variables in this study, i.e. debt covenant slack $\left(\mathrm{X}_{1}\right)$, earnings management $\left(\mathrm{X}_{2}\right)$, and value relevance (Y). The results of descriptive statistics are reported in Table 1.

Table 1

Descriptive Statistics of the Variables

\begin{tabular}{lcrrrr}
\hline & $\mathrm{N}$ & Minimum & Maximum & Mean & $\begin{array}{c}\text { Std. } \\
\text { Deviation }\end{array}$ \\
\hline Debt Covenant Slack $\left(\mathrm{X}_{1}\right)$ & 40 & $-4,350$ & 2,676 & 0,959 & 1,291 \\
$\begin{array}{l}\text { Earnings Management }\left(\mathrm{X}_{2}\right) \\
\text { Value Relevance }\end{array}$ & 40 & 0,014 & 0,836 & 0,188 & 0,187 \\
$(\mathrm{Y})$ & 40 & $-0,089$ & 0,595 & 0,147 & 0,184 \\
\hline
\end{tabular}

Table 1 shows that for the entire sample, debt covenant slack has a minimum value of $-4,350$ and a maximum value of 2,676 . The mean value of this variable is 0,959 . The standard deviation is 1,291 which are greater than the mean value. This means that on average, the variability of debt covenant slack value for the entire samples are relatively high. Earnings management proxies by the absolute discretionary accrual have a minimum and maximum value of 0,014 and 0,836 , respectively. The mean value of this variable is 0,959 and the standard deviation is 0,187 which are lower than the mean value. This means that on average, the variability of earnings management for the entire samples are relatively low. Value relevance has a minimum value of -0.089 and a maximum value of 0,595 . The mean value is 0,147 and the standard deviation is 0,184 which are greater than the mean value. This means that on average, the variability of earnings management for the entire samples are relatively high.

\section{Hypothesis Testing and Discussions}

Three hypotheses were tested using the Partial Least Square (PLS) approach and the results are presented in Table 2.

Table 2

Result of Hypothesis Testing

\begin{tabular}{ccccc}
\hline Hypothesis & Coefficient & t statistic & p value & Result \\
\hline $\mathrm{H}_{1}$ & 0,128 & 0,828 & 0,204 & Not Significant (Rejected) \\
$\mathrm{H}_{2}$ & $-0,227$ & 1,335 & 0,091 & Not Significant (Rejected) \\
$\mathrm{H}_{3}$ & 0,276 & 2,011 & 0,022 & Significant (Confirmed) \\
\hline
\end{tabular}

Dewi, N. P. S. P., \& Wirama, D. G. (2019). Debt covenant slack, earnings management, and value relevance of accounting information. International Research Journal of Management, IT and Social Sciences, 6(4), 86-96. https://doi.org/10.21744/irjmis.v6n4.661 
According to Table 2, the result did not support the first hypothesis $\left(\mathrm{H}_{1}\right)$ because the p-value is 0,204 which are greater than 0,05 . Hence, $\mathrm{H}_{1}$ is rejected, means that earnings management in the sample firms is not influenced by the firms' debt covenant slack.

This result does not confirm the debt covenant hypothesis, as well as the prior empirical evidence presented in Dyreng et al., (2011); Kim et al., (2010); Jha (2013); and Franz et al., (2014), which stated that the closeness of a firm to their debt covenant violations affect the earnings management. One that could be among the reason based on the data collected in this study is among the total of 40 sample firms, only four firms that had been violated the debt covenant (has negative slack), while the other empirical studies used the relatively similar amount between firms which are already in debt covenant violation and firms which are close to their debt covenant violation.

On the other hand, this finding is in line with the empirical evidence presented in Chung \& Kallapur (2003); Jao \& Pagalung (2011); and Ardison et al., (2012). Jao \& Pagalung (2011), stated that this condition might occur if the managers believe that earnings management is not the best way to do to avoid the violation of the firms' debt covenant. Research conducted by Dyreng (2007), found that the manager takes into account the cost of earnings management and so as the cost of debt covenant violation in deciding whether they will manage earnings or not. The evidence shows that the manager manages firms' earnings only if the cost of earnings management is lower than the cost of debt covenant violation. Managing earnings may lead the firms into some consequences including increasing regulatory scrutiny (Dechow et al., 1996), increasing the likelihood of shareholder litigation (Skinner, 1996), increasing taxable income (Dyreng, 2007), and sacrificing the real performance of the firm (Graham et al., 2004).

Based on Table 2 we can find that the result also did not support the second hypothesis $\left(\mathrm{H}_{2}\right)$ because the twentytwo $(0,091)$ is greater than 0,05 . Hence, $\mathrm{H}_{2}$ is rejected, means that the value relevance of firms' accounting information in this study did not affect by the earnings management which occurs in the firms. This finding is contrary to the prior empirical evidence presented by Whelan \& McNamara (2004); Habib (2004); Rahman (2009); Shan (2014); and Mostafa (2017), which found that earnings management has a negative effect on the value relevance of accounting information.

We have not found any prior empirical studies which obtained similar finding yet. But the study presented by Healy \& Wahlen (1999), found that earnings management activities occurred in the firms do not always influence the investors' decisions in using information about the firms' performance, earnings and book value. This is possible because investors consider earnings management is not pervasive. Investors are aware to the existence of earnings management because it can distort the firms' performance information, so that investors may make a decision that should not be made based on such information (Pae, 1999). However, if the investors consider that earnings management does not exceed the limits tolerated by them, they will still use the firms' performance information to predict the prospects of the firms (Kwag \& Stephens, 2010).

Table 2 also reported strong support for the third hypothesis $\left(\mathrm{H}_{3}\right)$, indicated by the $\mathrm{p}$-value $(0,022)$ which is lower than 0,05 . This means that the firms' debt covenant slack positively affect the value relevance of the firms' accounting information. This finding supports the empirical evidence from previous studies with similar topics conducted by Dhaliwal et al., (1990) and Moradi et al., (2010), which found that the greater the debt to equity ratio, the value relevance of firms' accounting information tends to be small.

This study found that the debt covenant slacks positively affect the investors' decision in using firms performance information i.e. earnings and book value. The smaller (tighter) the firms' debt covenant slack indicates that the firms' debt to equity ratio is relatively high. As stated by Dhaliwal et al., (1990), this condition causes the information of firms' performance to be less relevant for the investor because they will perceive that manager will prioritize the debt payment to the creditor rather than paying a dividend to the investor. Thus, the investor will not use the information to make a decision, thereby making the firms performance information loses its relevance.

\section{The Intervening Role (Mediation Effect) of Earnings Management}

This study did not find the mediation effect of earnings management on the effect of debt covenant slack on the value relevance of accounting information. This is because the debt covenant slack (as the independent variable) does not affect earnings management (as the variable which presumed as an intervening variable) and earnings management does not affect the value relevance of accounting information (dependent variable). 


\section{Conclusion}

This study did not find evidence supported the debt covenant hypothesis and previous empirical evidence that the debt covenant violations negatively affect earnings management. This study also did not obtain any empirical evidence in line with previous research which found that earnings management negatively affects the value relevance of accounting information.

On the other hand, this study found that the firms' debt covenant slack positively affect the value relevance of its accounting information. Thus, we can conclude that the information about the firms' debt covenant slack is also being a consideration of investors in deciding whether to use information about firms' performance or not. This finding can lead to a suggestion for managers to maintain the firms' financial ratios appropriately in order to not to close or exceeded the maximum or minimum ratio required on their debt covenant with the creditors.

This study is limited in its small number of samples because of the use of value relevance proxies. Therefore, further research with a similar topic may utilize the other proxy to measure the value relevance of accounting information.

Conflict of interest statement and funding sources

The authors declared that they have no competing interest.

Statement of authorship

The authors have a responsibility for the conception and design of the study. The authors have approved the final article.

\section{Acknowledgments}

The authors would like to thank the Editor of IRJMIS for their valuable time, support, and advice in completing the current study.

Dewi, N. P. S. P., \& Wirama, D. G. (2019). Debt covenant slack, earnings management, and value relevance of accounting information. International Research Journal of Management, IT and Social Sciences, 6(4), 86-96. 


\section{References}

Ardison, K. M. M., Martinez, A. L., \& Galdi, F. C. (2012). The effect of leverage on earnings management in Brazil. Advances in Scientific and Applied Accounting, 5(3), 305-324.

Ball, R., \& Brown, P. (1968). An empirical evaluation of accounting income numbers. Journal of accounting research, 159-178. https://doi.org/10.2307/2490232

Barth, M. E., Beaver, W. H., \& Landsman, W. R. (2001). The relevance of the value relevance literature for financial accounting standard setting: another view. Journal of accounting and economics, 31(1-3), 77-104. https://doi.org/10.2139/ssrn.228950

Brown, S., Lo, K., \& Lys, T. (1999). Use of R2 in accounting research: measuring changes in value relevance over the last four decades. Journal of Accounting and Economics, 28(2), 83-115. https://doi.org/10.1016/S01654101(99)00023-3

Chandrapala, P. (2013). The value relevance of earnings and book value: The Importance of ownership concentration and firm size. Journal of Competitiveness, 5(2), 98-107. https://doi.org/10.7441/joc.2013.02.07

Chung, H., \& Kallapur, S. (2003). Client importance, nonaudit services, and abnormal accruals. The Accounting Review, 78(4), 931-955. https://doi.org/10.2308/accr.2003.78.4.931

DeAngelo, H., DeAngelo, L., \& Skinner, D. J. (1994). Accounting choice in troubled companies. Journal of accounting and economics, 17(1-2), 113-143. https://doi.org/10.1016/0165-4101(94)90007-8

Dechow, P. M., Sloan, R. G., \& Sweeney, A. P. (1995). Detecting earnings management. Accounting review, $193-225$. https://doi.org/10.2307/248303

Dechow, P. M., Sloan, R. G., \& Sweeney, A. P. (1996). Causes and consequences of earnings manipulation: An analysis of firms subject to enforcement actions by the SEC. Contemporary accounting research, 13(1), 1-36. https://doi.org/10.1111/j.1911-3846.1996.tb00489.x

Demerjian, P. R., \& Owens, E. (2014). Measuring financial covenant strictness in private debt contracts. SSRN Electronic Journal. https://doi.org/10.2139/ssrn.2232880

Dewi, I. G. A. A. O., Dewi, I. G. A. A. P., Kustina, K. T., \& Prena, G. D. (2018). Culture of tri hita karana on ease of use perception and use of accounting information system. International Journal of Social Sciences and Humanities, 2(2), 77-86. https://doi.org/10.29332/ijssh.v2n2.131

Dhaliwal, D. S., Lee, K. J., \& Fargher, N. L. (1991). The association between unexpected earnings and abnormal security returns in the presence of financial leverage. Contemporary Accounting Research, 8(1), $20-41$. https://doi.org/10.1111/j.1911-3846.1991.tb00832.x

Dichev, I. D., \& Skinner, D. J. (2002). Large-sample evidence on the debt covenant hypothesis. Journal of accounting research, 40(4), 1091-1123. https://doi.org/10.1111/1475-679X.00083

Duke, J. C., \& Hunt III, H. G. (1990). An empirical examination of debt covenant restrictions and accounting-related debt proxies. Journal of accounting and Economics, 12(1-3), 45-63. https://doi.org/10.1016/0165-4101(90)900412

Dyreng, S. D. (2008). The cost of private debt covenant violation. The University of North Carolina at Chapel Hill.

Dyreng, S., Hillegeist, S., \& Penalva, F. (2011). Earnings management to avoid debt covenant violations and future performance. Working Paper, Duke University, Arizona State University.

Frantz, P. (1997). Discretionary Accounting Choices: A Debt covenants Based Signalling Approach. Accounting and Business Research, 27(2), 99-110. https://doi.org/10.1080/00014788.1997.9729537

Franz, D. R., HassabElnaby, H. R., \& Lobo, G. J. (2014). Impact of proximity to debt covenant violation on earnings management. Review of Accounting Studies, 19(1), 473-505. https://doi.org/10.1007/s11142-013-9252-9

Graham, J. R., Harvey, C. R., \& Rajgopal, S. (2005). The economic implications of corporate financial reporting. Journal of accounting and economics, 40(1-3), 3-73. https://doi.org/10.1016/j.jacceco.2005.01.002

Habib, A. (2004). Impact of earnings management on value-relevance of accounting information: Empirical evidence from Japan. Managerial Finance, 30(11), 1-15. https://doi.org/10.1108/03074350410769344

Healy, P. M., \& Wahlen, J. M. (1999). A review of the earnings management literature and its implications for standard setting. Accounting horizons, 13(4), 365-383. https://doi.org/10.2139/ssrn.156445

Herawati, N. (2007). Manajemen Laba pada perusahaan yang melanggar perjanjian utang (Doctoral dissertation, Universitas Gadjah Mada).

Jao, R., \& Pagalung, G. (2011). Corporate governance, ukuran perusahaan, dan leverage terhadap manajemen laba perusahaan manufaktur Indonesia. Jurnal akuntansi dan auditing, 8(1), 43-54.

Jensen, M. C., \& Meckling, W. H. (1976). Theory of the firm: Managerial behavior, agency costs and ownership structure. Journal of financial economics, 3(4), 305-360. https://doi.org/10.2139/ssrn.94043 
Jha, A. (2013). Earnings management around debt-covenant violations-An empirical investigation using a large sample of quarterly data. Journal of Accounting, Auditing \& Finance, 28(4), 369-396. https://doi.org/10.1177/0148558X13505597

Kim, B. H., Lisic, L. L., \& Pevzner, M. (2010). Debt covenant slack and real earnings management. George Mason University, Working Paper. https://doi.org/10.2139/ssrn.1701218

Kusuma, P. S. A. J., \& Yasa, G. W. (2019). Comparative analysis of company market reactions on right issue for pay debt and investment. International Research Journal of Management, IT and Social Sciences, 6(3), 29-36. https://doi.org/10.21744/irjmis.v6n3.626

Kwag, S. W., \& Stephens, A. A. (2009). Investor reaction to earnings management. Managerial Finance, 36(1), 4456. https://doi.org/10.1108/03074351011006838

Lee, S. F., \& Sai On Ko, A. (2000). Building balanced scorecard with SWOT analysis, and implementing "Sun Tzu's The Art of Business Management Strategies" on QFD methodology. Managerial Auditing Journal, 15(1/2), 68-76. https://doi.org/10.1108/02686900010304669

Leftwich, R. (1983). Accounting information in private markets: Evidence from private lending agreements. Accounting Review, 23-42.

Lev, B. (1989). On the usefulness of earnings and earnings research: Lessons and directions from two decades of empirical research. Journal of accounting research, 27, 153-192. https://doi.org/10.2307/2491070

Lev, B., \& Zarowin, P. (1999). The boundaries of financial reporting and how to extend them. Journal of Accounting research, 37(2), 353-385. https://doi.org/10.2307/2491413

Mandala, I. G. N. A. K., \& Astika, I. B. P. (2019). Effect of work environment, quality of system and work culture on satisfaction of accounting information system user. International Research Journal of Management, IT and Social Sciences, 6(4), 37-43. https://doi.org/10.21744/irjmis.v6n4.633

Moradi, M., Salehi, M., \& Erfanian, Z. (2010). A Study of the Effect of Financial Leverage on Earnings Response Coefficient through out Income Approach: Iranian Evidence. International Review of Accounting, Banking and Finance, 2(2), 104-116.

Mostafa, W. (2017). The impact of earnings management on the value relevance of earnings: Empirical evidence from Egypt. Managerial Auditing Journal, 32(1), 50-74. https://doi.org/10.1108/MAJ-01-2016-1304

Pae, J. (1999). Earnings management and its impact on the information content of earnings and the properties of analysts forecasts (Doctoral dissertation, University of British Columbia). https://doi.org/10.14288/1.0089242

Press, E. G., \& Weintrop, J. B. (1990). Accounting-based constraints in public and private debt agreements: Their association with leverage and impact on accounting choice. Journal of accounting and economics, 12(1-3), 65-95. https://doi.org/10.1016/0165-4101(90)90042-3

Rahman, A. F. (2018). Masalah Keagenan Aliran Kas Bebas, Manajemen Laba dan Relevansi Nilai Informasi Akuntansi. EKUITAS (Jurnal Ekonomi dan Keuangan), 15(2), 232-246. https://doi.org/10.24034/j25485024.y2011.v15.i2.2290

Shan, Y. G. (2015). Value relevance, earnings management and corporate governance in China. Emerging Markets Review, 23, 186-207. https://doi.org/10.1016/j.ememar.2015.04.009

Skinner, D. J. (1997). Earnings disclosures and stockholder lawsuits. Journal of accounting and economics, 23(3), 249-282. https://doi.org/10.1016/S0165-4101(97)00010-4

Sukardi, I. M. (2019). The effect of information technology relatedness on union performance mediated by knowledge management capability. International Research Journal of Management, IT and Social Sciences, 6(3), 46-60. https://doi.org/10.21744/irjmis.v6n3.623

Sweeney, A. P. (1994). Debt-covenant violations and managers' accounting responses. Journal of accounting and Economics, 17(3), 281-308. https://doi.org/10.1016/0165-4101(94)90030-2

Watts, R. L., \& Zimmerman, J. L. (1978). Towards a positive theory of the determination of accounting standards. Accounting review, 112-134.

Watts, R. L., \& Zimmerman, J. L. (1990). Positive accounting theory: a ten year perspective. Accounting review, 131156.

Whelan, C., \& McNamara, R. (2004). The impact of earnings management on the value-relevance of financial statement information. Available at SSRN 585704. https://doi.org/10.2139/ssrn.585704

Widowati, D., Nugrahanti, Y., \& Kristanto, A. B. (2015). Analisis Faktor Keuangan dan Non Keuangan Yang Berpengaruh Pada Prediksi Peringkat Obligasi di Indonesia (Studi Pada Perusahaan Non Keuangan Yang Terdaftar di BEI dan di Daftar Peringkat PT Pefindo 2009-2011). Jurnal Manajemen Maranatha, 13(1).

Dewi, N. P. S. P., \& Wirama, D. G. (2019). Debt covenant slack, earnings management, and value relevance of accounting information. International Research Journal of Management, IT and Social Sciences, 6(4), 86-96.

https://doi.org/10.21744/irjmis.v6n4.661 
Widyatama, W. W., \& Wirama, D. G. (2018). The effect of accounting conservatism on the value relevance of accounting information: Evidence from Indonesia. European Journal of Business and Social Sciences, 6(4), 34-46. 